\title{
AIMED CONTROL OF THE FREQUENCY SPECTRUM OF EIGENVIBRATIONS OF ELASTIC PLATES WITH A FINITE NUMBER OF DEGREES OF FREEDOM OF MASSES BY SUPERIMPOSING ADDITIONAL CONSTRAINTS
}

\author{
Leonid S. Lyakhovich ${ }^{1}$, Pavel A. Akimov ${ }^{2}$ \\ ${ }^{1}$ Tomsk State University of Architecture and Civil Engineering, Tomsk, RUSSIA \\ ${ }^{2}$ National Research Moscow State University of Civil Engineering, Moscow, RUSSIA
}

\begin{abstract}
As is known, for some elastic systems with a finite number of degrees of freedom of masses, for which the directions of motion of the masses are parallel and lie in the same plane, methods have been developed for creating additional constraints that purposefully change the spectrum of natural frequencies. In particular, theory and algorithm for the formation of aimed additional constraints have been developed for the rods, the introduction of each of which does not change any of the modes of natural vibrations, but only increases the value of only one frequency, without changing the values of the remaining frequencies. The distinctive paper is devoted to the method of forming a matrix of additional stiffness coefficients corresponding to such aimed constraint in the problem of natural vibrations of rods. This method can also be applied to solving a similar problem for elastic systems with a finite number of degrees of freedom, in which the directions of motion of the masses are parallel, but not lie in the same plane. In particular, such systems include plates. However, the algorithms for the formation of aimed additional constraints, developed for rods and based on the properties of rope polygons, cannot be used without significant changes in a similar problem for plates. The method for the formation of design constraint schemes that purposefully change the spectrum of frequencies of natural vibrations of elastic plates with a finite number of degrees of freedom of masses, will be considered in the next work.
\end{abstract}

Keywords: frequency of natural vibrations, form of natural vibrations, aimed constraint, additional constraint, stiffness coefficients

\section{ПРИЦЕЛЬНОЕ РЕГУЛИРОВАНИЕ СПЕКТРА ЧАСТОТ СОБСТВЕННЫХ КОЛЕБАНИЙ УПРУГИХ ПЛАСТИН С КОНЕЧНЫМ ЧИСЛОМ СТЕПЕНЕЙ СВОБОДЫ МАСС ПУТЁМ НАЛОЖЕНИЯ ДОПОЛНИТЕЛЬНЫХ СВЯЗЕЙ}

\author{
Л.С. Ляхович ${ }^{1}$, П.А. Акимов ${ }^{2}$ \\ ${ }^{1}$ Томский государственный архитектурно-строительный университет, г. Томск, РОССИЯ \\ ${ }^{2}$ Национальный исследовательский Московский государственный строительный университет, г. Москва, РОС-
} СИЯ

\begin{abstract}
Аннотация: К настоящему времени для некоторых упругих систем с конечным числом степеней свободы масс, у которых направления движения масс параллельны и лежат в одной плоскости, разработаны методы создания дополнительных связей прицельно изменяющих спектр частот собственных колебаний. В частности, для стержней разработаны теория и алгоритм формирования прицельных дополнительных связей, введение каждой из которых не изменяет ни одну из форм собственных колебаний, а лишь увеличивает значение только одной частоты, не изменяя величин остальных частот. В данной статье показано, что метод формирования матрицы дополнительных коэффициентов жесткости, характеризующих такую прицельную связь в задаче о собственных колебаниях стержней, может быть применен и при решении аналогичной задачи для упругих систем с конечным числом степеней свободы, у которых направления движения масс параллельны, но не лежат в одной плоскости. В частности, к таким системам относятся пластины. Однако, алгоритмы формирования прицельных дополнительных связей, разработанные для стержней на основе свойств верёвочных многоугольников, не могут быть без существенных
\end{abstract}


Aimed Control of the Frequency Spectrum of Eigenvibrations of Elastic Plates with a Finite Number of Degrees of Freedom of Masses by Superimposing Additional Constraints

изменений использованы в аналогичной задаче для пластин. Метод формирования расчётных схем связей, прицельно изменяющих спектр частот собственных колебаний упругих пластин с конечным числом степеней свободы масс, будет рассмотрен в следующей работе.

Ключевые слова: частота собственных колебаний, форма собственных колебаний, прицельная связь, дополнительная связь, коэффициенты жесткости

When designing structures, in some cases it becomes necessary to deduce one or several natural frequencies from a certain frequency interval. As is known (see, for instance, [1-5]), one of the methods for solving such a problem is the creation of aimed generalized constraints. Each of aimed generalized constraints increases the value of only one selected natural frequency to a predetermined value in advance, without changing the rest of the natural frequencies and all natural modes.

In the above-mentioned works for elastic rods carrying a finite amount of concentrated masses (corresponding sample is presented in Figure $1 a$ ), a method was developed for creating aimed constraints. The principal system of the displacement method was chosen (Figure $1 b$ ). The equations of the displacement method were written in the form traditional for systems with a finite number of degrees of freedom $(n)$

$$
\begin{aligned}
& \left(r[1,1]+m[1] \omega^{2}\right) v[1, j]+r[1,2] v[2, j]+\ldots \\
& \quad+r[1, q] v[q, j]+\ldots+r[1, n] v[n, j]=0 \\
& r[2,1] v[1, j]+\left(r[2,2]+m[2] \omega^{2}\right) v[2, j]+\ldots \\
& \quad+r[2, q] v[q, j]+\ldots+r[2, n] v[n, j]=0
\end{aligned}
$$$$
\begin{aligned}
& r[n, 1] v[1, j]+r[n, 2] v[2, j]+\ldots+r[n, q] v[q, j]+ \\
& \quad+\ldots+\left(r[n, n]+m[n] \omega^{2}\right) v[n, j]=0
\end{aligned}
$$

It should be noted that elements $r[i, k]$ form a matrix of stiffness coefficients, $A=\|r[i, k]\|$; $m[i]$ are masses, which form a diagonal matrix, $M=\|m[i]\| ; \omega$ is the natural frequency of the system; $v[k, j]$ are displacements in the direction of motion of the masses in the $j$-th $((j=1,2, . ., q, . . ., n))$ natural mode.
Roots of the equation

$$
\left|A-\omega^{2} M\right|=0
$$

determine the spectrum of natural frequencies of the system

$$
\omega[1], \omega[2], \ldots, \omega[q-1], \omega[q], \omega[q+1], \ldots, \omega[n] .
$$

The problem of creation of aimed constraint, which increases only one natural frequency (for instance, $\omega[q])$ to a predetermined value $(\omega s)$ in advance and does not change any of the natural modes and the values of the remaining frequencies of the spectrum is under consideration. It is shown that the creation of such constraint is based on the formation of a matrix of additional stiffness coefficients

$$
\begin{aligned}
& \qquad A_{0}=A_{S O} A_{S}=A_{S O}\left\|a_{0}[i, k]\right\|_{i, k=1}^{n}, \\
& \text { where } \quad A_{S}=\left\|a_{0}[i, k]\right\|_{i, k=1}^{n} .
\end{aligned}
$$

The matrix $A_{0}$ must have special properties. If the introduced constraint is "aimed" at the $q$-th natural frequency, then the stiffness coefficients $\left\|a_{0}[i, k]\right\|_{i, k=1}^{n}$ should be orthogonal to the coordinates of the natural modes corresponding to the remaining $(n-1)$ frequencies of the spectrum.

Thus, we have

$$
\begin{aligned}
& \sum_{k=1}^{n} a_{0}[i, k] v[k, j]=0, \\
& \quad(i=1,2, . ., n, j=1,2, . .,(q-1),(q+1), . ., n)
\end{aligned}
$$




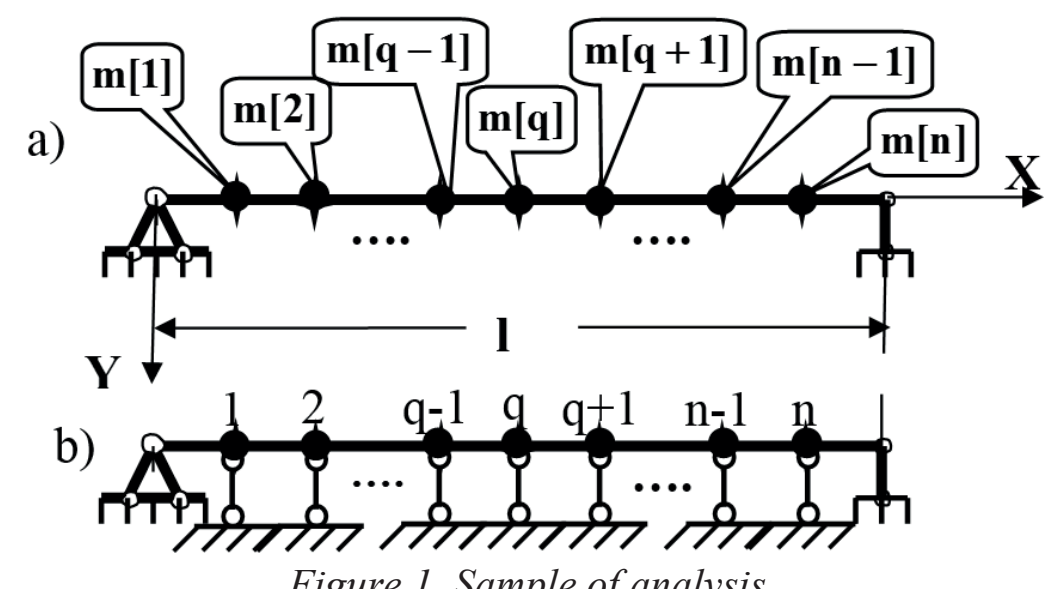

Figure 1. Sample of analysis.

The coefficients are not orthogonal with respect to the $q$-th natural frequency, at which the introduced constraint is "aimed". We have

$$
\sum_{k=1}^{n} a_{0}[i, k] v_{\omega}[k, q] \neq 0, \quad(i=1,2, . ., n)
$$

It is shown (for instance, [2-5]) that conditions (6) and (7) will be satisfied by the coefficients

$$
a_{0}[i, k]=m[i] m[k] v_{\omega}[i, q] v_{\omega}[k, q] .
$$

The value of the factor $A_{S O}$ is defined as the root of the equation

$$
\left|\left(A-\omega_{S}^{2} M\right)+A_{S O} A_{S}\right|=0 .
$$

Since the $q$ th natural mode of the original system remains natural mode after the introduction of the aimed constraint and at the frequency $\omega_{S}$, the factor $A_{S O}$ can be found as

$$
A_{S O}=\frac{-\sum_{i=1}^{n} \sum_{k=1}^{n}\left(a[i, k]-\omega_{S}^{2} m[i, k]\right) v_{\omega}[i, q] v_{\omega}[k, q]}{\sum_{i=1}^{n} \sum_{k=1}^{n} a_{0}[i, k] v_{\omega}[i, q] v_{\omega}[k, q]} .
$$

The result of solving the equation

$$
\left|\left(A+A_{S O} A_{S}\right)-\omega^{2} M\right|=0 .
$$

must confirm that the natural modes have not changed, and the aimed frequency has increased to $\omega_{S}$.

The supporting device, which will correspond to the matrix of additional stiffness coefficients, must ensure the relationship between the nodal displacements is the same as between the coordinates of the $q$-th form of natural modes of the original system. It has been shown (see, for instance, [2-5]) that such a relationship will be realized if the additional support system transfers forces to the nodes of the main system of the bar. The relationships between which are proportional to the values

$$
R_{0}[i]=m[i] v[i,(q)]
$$

An example of such a generalized aimed constraint for a rod is a sprengel, the outline of which is determined by a rope polygon built in the plane of motion of masses by forces (see, for instance, [2-5]).

This constraint is once statically undefined. Vertical posts of constraint are installed in the nodes of the main system in the direction of mass movement. The prestressing of any one rod will cause such forces in the truss struts, the ratios between which will be the same as the ratios between the forces $R_{0}[i]$.

The distinctive paper is devoted to the problem of creating of aimed constraint for elastic plates carrying a finite number of concentrated masses. 
a)

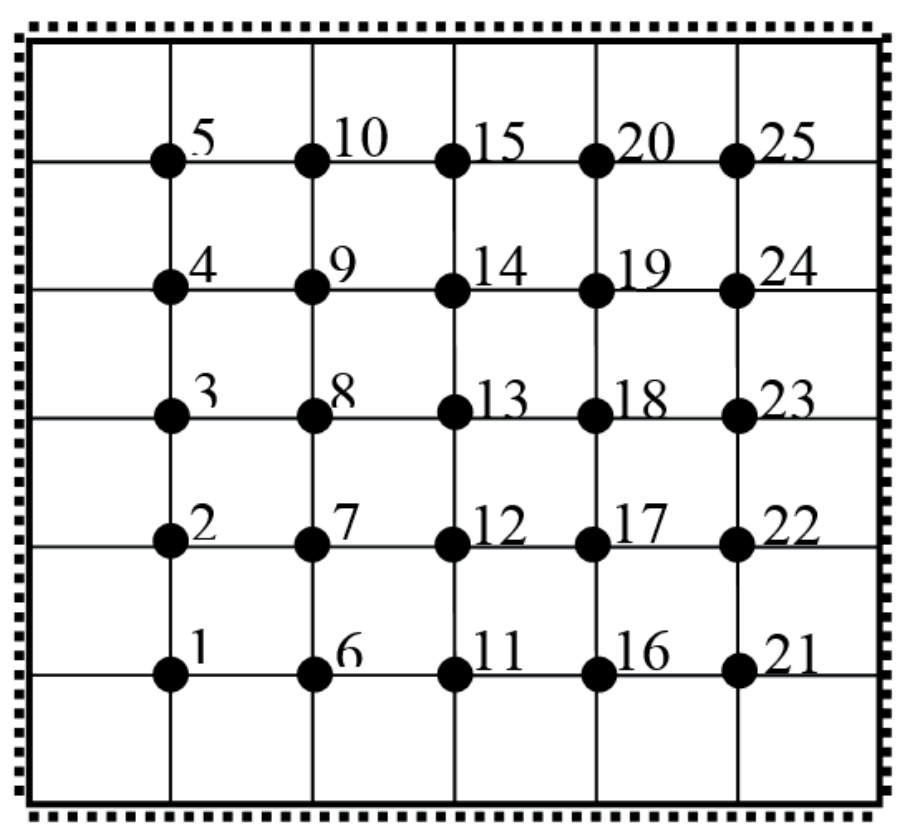

b)

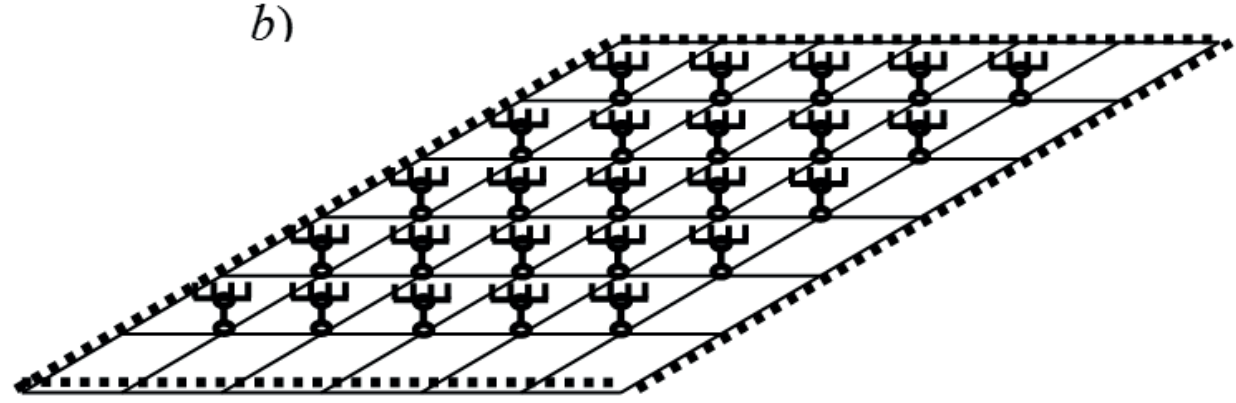

Figure 2. Sample of plate and principal system of the displacement method.

As in a similar problem for the rods, it is proposed to use the principal system of the displacement method. Examples of such a plate and the corresponding principal system of the displacement method are shown in Figures $2 a$ and $2 b$.

If we accept one-dimensional numbering in the method of displacements for plates, then the equations in this case will also be written in the form (1). Additional constraints in the principal system and displacements $v[k, j]$ in the equations correspond to the direction of motion of the masses.

The derivation of the expressions for the coefficients of the matrix of additional stiffnesses (4) for the rods is based on the properties of the natural modes.

Since the natural modes of the plates, as well as for rods, are orthogonal,

$$
\sum_{k=1}^{n} m[k] v_{\omega}[k, q] v_{\omega}[k, j]=0, \quad(q \neq j)
$$

then the problem for elastic plates carrying a finite number of concentrated masses, as well as for rods, will be based on the formation of a matrix of additional stiffness coefficients (4). The coefficients $\left\|a_{0}[i, k]\right\|_{i, k=1}^{n}$ must also satisfy conditions (6) and (7) and be determined by dependencies (8).

Let us give an example that confirms that the matrix of additional stiffness coefficients (4) serves as the basis for creating aimed constraints also for elastic plates carrying a finite number of concentrated masses.

Let us consider a plate carrying 25 concentrated masses (Figure 1a). 
Table 1. The values of the first five frequencies of natural modes of the plate and the coordinates of their corresponding natural modes.

\begin{tabular}{|c|c|c|c|c|c|c|c|c|c|c|}
\hline & \multicolumn{5}{|c|}{ Initial frequencies and modes } & \multicolumn{5}{|c|}{ Modified frequencies and modes } \\
\hline$w$ & 36.6583 & 91.0084 & 92.7466 & 146.834 & 178.911 & 91.0084 & 92.7466 & 100.00 & 146.8337 & 178.911 \\
\hline 1 & 0.0830 & 0.1995 & 0.0499 & -0.2495 & 0.1547 & -0.1995 & -0.0499 & 0.0830 & -0.2495 & 0.1547 \\
\hline 2 & 0.1434 & 0.2935 & -0.0043 & -0.2433 & -0.0063 & -0.2935 & 0.0043 & 0.1434 & -0.2433 & -0.0063 \\
\hline 3 & 0.1649 & 0.2568 & -0.1468 & 0.0129 & -0.1657 & -0.2568 & 0.1468 & 0.1649 & 0.0129 & -0.1657 \\
\hline 4 & 0.1420 & 0.1514 & -0.2494 & 0.2641 & -0.0063 & -0.1514 & 0.2494 & 0.1420 & 0.2641 & -0.0063 \\
\hline 5 & 0.0818 & 0.0579 & -0.1971 & 0.2624 & 0.1548 & -0.0579 & 0.1971 & 0.0818 & 0.2624 & 0.1548 \\
\hline 6 & 0.1441 & 0.2533 & 0.1398 & -0.2517 & 0.2788 & -0.2533 & -0.1398 & 0.1441 & -0.2517 & 0.2788 \\
\hline 7 & 0.2492 & 0.3484 & 0.0840 & -0.2447 & 0.0003 & -0.3484 & -0.0840 & 0.2492 & -0.2447 & 0.0003 \\
\hline 8 & 0.2867 & 0.2601 & -0.1502 & 0.0123 & -0.2788 & -0.2601 & 0.1502 & 0.2867 & 0.0123 & -0.2788 \\
\hline 9 & 0.2468 & 0.1025 & -0 . & 0.2 & 0.0003 & -0.1025 & 15 & 0.2468 & 0.2 & 0.0003 \\
\hline 10 & 0.1423 & 0.0090 & -0.2912 & 0.2642 & 0.2789 & -0.0090 & 0.2912 & 0.1423 & 0.2642 & 0.2789 \\
\hline 11 & 0.1672 & 0.1467 & 0.2455 & -0.0058 & 0.3359 & -0.1467 & -0.2455 & 0.1672 & -0.0058 & 0.3359 \\
\hline 12 & 0.2895 & 0.1491 & 0.2411 & -0.0017 & 0.0088 & -0.1491 & -0.2411 & 0.2895 & -0.0017 & 0.0088 \\
\hline 13 & 0.3336 & 0.0082 & -0.0119 & 0.0070 & -0.3237 & -0.0082 & 0.0119 & 0.3336 & 0.0070 & -0.3237 \\
\hline 14 & 0.2877 & -0.1313 & -0.2630 & 0.0124 & 0.0088 & 0.1313 & 0.2630 & 0.2877 & 0.0124 & 0.0088 \\
\hline 15 & 0.1657 & -0.1331 & -0.2605 & 0.0131 & 0.3359 & 0.1331 & 0.2605 & 0.1657 & 0.0131 & 0.3359 \\
\hline 16 & 0.1454 & 0.0007 & 0.2856 & 0.2417 & 0.3025 & -0.0007 & -0.2856 & 0.1454 & 0.2417 & 0.3025 \\
\hline 17 & 0.2522 & \begin{tabular}{|c|}
-0.0908 \\
\end{tabular} & 0.3339 & 0.2415 & 0.0119 & 0.0908 & -0.3339 & 0.2522 & 0.2415 & 0.0119 \\
\hline 18 & 0.2915 & -0.2485 & 0.1317 & -0.0018 & -0.2941 & 0.2485 & -0.1317 & 0.2915 & -0.0018 & -0.2941 \\
\hline 19 & 0.2513 & -0.3314 & -0.1103 & -0.2446 & 0.0118 & 0.3314 & 0.1103 & 0.2513 & -0.2446 & 0.0118 \\
\hline 20 & 0.1446 & -0.2398 & -0.1592 & -0.2432 & 0.3025 & 0.2398 & 0.1592 & 0.1446 & -0.2432 & 0.3025 \\
\hline 21 & 0.0842 & -0.0528 & 0.1956 & 0.2437 & 0.1811 & 0.0528 & -0.1956 & 0.0842 & 0.2437 & 0.1811 \\
\hline 22 & 0.1461 & -0.1445 & 0.2454 & 0.2416 & 0.0151 & 0.1445 & -0.2454 & 0.1461 & 0.2416 & 0.0151 \\
\hline 23 & 0.1688 & -0.2486 & 0.1349 & \begin{tabular}{|l|}
-0.0059 \\
\end{tabular} & -0.1580 & 0.2486 & -0.1349 & 0.1688 & -0.0059 & -0.1580 \\
\hline 24 & 0.1457 & -0.2827 & -0.0135 & -0.2517 & 0.0151 & 0.2827 & 0.0135 & 0.1457 & -0.2517 & 0.0151 \\
\hline 25 & 0.0838 & -0.1910 & -0.0633 & -0.2494 & 0.1811 & 0.1910 & 0.0633 & 0.0838 & -0.2494 & 0.1811 \\
\hline
\end{tabular}

In node 9, the mass is equal to $600 \mathrm{~kg}$, in node 18 it is equal to $1000 \mathrm{~kg}$, and in the rest of the nodes it is equal to $800 \mathrm{~kg}$. The dimensions of the plate in the plan are equal to 6 and 6 meters ( $m$ ), the thickness is equal to 0.12 meters. The modulus of elasticity of the plate material is equal to $E=24000000000 \mathrm{~N} / \mathrm{m}^{2}$, Poisson's ratio $v_{0}=0.2$. With the principal system of the displacement method (Figure 2b) and onedimensional numbering of values in accordance with Figure $2 a$, the spectrum of natural frequencies is determined as the roots of equation (2). The values of the first five frequencies of natural modes of the plate and the coordinates of their corresponding natural modes are given in Table 1 (columns are initial frequencies and modes).
Suppose now it is required to increase the value of the first natural frequency to $100 \mathrm{sec}^{-1}$. For this, in accordance with (8)-(10), we will form a matrix of additional stiffness coefficients. All data necessary for using dependencies (8)-(10) are given in Table 1 (columns are initial frequencies and modes).

After the formation of the matrix of additional stiffness coefficients with allowance for their influence, we determine from equation (11) the modified spectrum of natural frequencies and the corresponding natural modes.

The first five natural frequencies and their corresponding natural modes are shown in Table 1 (columns are modified frequencies and modes). It can be seen from the table that taking into account additional stiffness coefficients did not change any of the natural modes of the plate, 
but only increased the value of one of the frequencies from $36.6583 \mathrm{~s}-1$ to a given value of $100 \mathrm{~s}-1$. This result clearly illustrates the possibility of using dependencies (5), (8)-(10) for solving the problem of aimed constraints for elastic plates with a finite number of degrees of freedom of masses.

The generalized aimed constraint for the plate, as well as for the rod, should create additional stiffness, ensuring the aiming of the constraint.

As noted above, the properties of the aimed constraints for the rods are based on the properties of the natural modes. The properties used here can be also applied to elastic plates. This circumstance serves as a justification for using the results of formulating the properties of aimed constraints for rods and in a similar problem for plates.

Thus, the matrix of additional stiffness coefficients (4) must correspond to the generalized aimed constraint in case of the plate. If the design scheme of the constraint is represented by a variant of the hinge-rod system, then it must be statically indeterminate once.

In the nodes of the plate where the masses are located, posts are installed in the direction of movement of the masses, and the preliminary stress of any one element of constraint causes such forces in the posts of the system, the relations between which are proportional to the relationship between the stresses (12). At the same time, there should be no connections with the plate in the structure of the constraint, except for the posts installed in the nodes of the plate, where the masses are located.

Design schemes of generalized aimed constraints that meet the above requirements are multivariate and depend on the shape of the plate, the locations of the masses and some other features of the original object. Taking this circumstance into account, the approaches and algorithms for the formation of design schemes of constraint that purposefully change the spectrum of natural frequencies of elastic plates with a finite number of degrees of freedom of masses represent a separate problem and will be considered in the next research work.
So, this paper shows that the method of forming a matrix of additional stiffness coefficients that determine the aimed constraint in the problem of natural vibrations of rods can also be used to solve a similar problem for elastic systems with a finite number of degrees of freedom of masses, for which the directions of motion of the masses are parallel, but do not lie in the same plane.

The paper also substantiates and formulates the properties and requirements to which the design schemes of aimed constraints in the problem under consideration must correspond.

\section{REFERENCES}

1. Nudelman Ya.L. Metody Opredelenija Sobstvennyh Chastot i Kriticheskih Sil Dlja Sterzhnevyh Sistem [Methods for Determining Natural Frequencies and Critical Forces for Rod Systems]. Moscow, Gostekhizdat, 1949, 175 pages (in Russian).

2. Nudelman Ya.L., Lyakhovich L.S., Giterman D.M. O naibolee Podatlivyh Svjazjah Naibol'shej Zhestkosti [About the Most Yielding Constraints of the Greatest Rigidity]. // Problems of Applied Mechanics and Mathematics, Tomsk, TSU Publishing House, 1981, pp. 113-126 (in Russian).

3. Giterman D.M., Lyakhovich L.S., Nu-delman Ya.L. Algoritm Sozdanija Rezonansno-bezopasnyh Zon Pri Pomoshhi Nalozhenija Dopolnitel'nyh Svjazej [Algorithm for Creating Resonance-Safe Zones by Imposing Additional Constraints]. // Dynamics and Strength of Machines, Vol. 39, Kharkov, "Vishcha Schkola", 1984, pp. 63-69 (in Russian).

4. Lyakhovich L.S., Maletkin O.Yu. O Pricel'nom Regulirovanii Sobstvennyh Chastot Uprugih Sistem [About Aimed Control of Natural Frequencies of Elastic Systems]. // Izvestia Vuzov. Construction and Architecture, 1990, No. 1, pp. 113-117 (in Russian).

5. Lyakhovich L.S. Osobye Svojstva Optimal'nyh Sistem i Osnovnye Napravlenija ih Realizacii 
v Metodah Rascheta Sooruzhenij [Special Properties of Optimal Systems and the Main Directions of Their Implementation in the Methods of Calculation of Structures]. Tomsk, Tomsk State University of Architecture and Construction, 2009, 372 pages (in Russian).

\section{СПИСОК ЛИТЕРАТУРЫ}

1. Нудельман Я.Л. Методы определения собственных частот и критических сил для стержневых систем. - М.: Гостехиздат, 1949. - 175 c.

2. Нудельман Я.Л., Ляхович Л.С., Гитерман Д.М. О наиболее податливых связях наибольшей жесткости. // Вопросы прикладной механики и математики, Томск, Издательство ТГУ, 1981, с. 113-126.
3. Гитерман Д.М., Ляхович Л.С., Нудельман Я.Л. Алгоритм создания резонанснобезопасных зон при помощи наложения дополнительных связей. // Динамика и прочность машин, Вып. 39, Харьков, «Вища школа», 1984, с. 63-69.

4. Ляхович Л.С., Малеткин О.Ю. О прицельном регулировании собственных частот упругих систем. // Известия вузов. Строительство и архитектура, 1990, №1, с. 113-117.

5. Ляхович Л.С. Особые свойства оптимальных систем и основные направления их реализации в методах расчета сооружений. Томск: Издательство Томского государственного архитектурностроительного университета, 2009. 372 c.
Leonid S. Lyakhovich, Full Member of the Russian Academy of Architecture and Construction Sciences, Professor, DSc, Head of Department of Structural Mechanics, Tomsk State University of Architecture and Building; 634003, Russia, Tomsk, Solyanaya St., 2; E-mail: 1ls@tsuab.ru

Pavel A. Akimov, Full Member of the Russian Academy of Architecture and Construction Sciences, Professor, Dr.Sc.; Acting Rector of National Research Moscow State University of Civil Engineering; Professor of Department of Architecture and Construction, Peoples' Friendship University of Russia; Professor of Department of Structural Mechanics, Tomsk State University of Architecture and Building; 24, Ul. Bolshaya Dmitrovka, 107031, Moscow, Russia; phone +7(495) 625-71-63; Fax: +7 (495) 650-27-31; E-mail: akimov@raasn.ru,pavel.akimov@gmail.com.
Ляхович Леонид Семенович, академик РААСН, профессор, доктор технических наук, профессор кафедры строительной механики, Томский государственный архитектурно-строительный университет; 634003, Россия, г. Томск, Соляная пл. 2; E-mail: 1ls@tsuab.ru

Акимов Павел Алексеевич, академик РААСН, профессор, доктор технических наук; временно исполняющий обязанности ректора Национального исследовательского Московского государственного строительного университета; профессор Департамента архитектуры и строительства Российского университета дружбы народов; профессор кафедры строительной механики Томского государственного архитектурно-строительного университета; 107031, г. Москва, ул. Большая Дмитровка, д. 24, стр. 1; тел. +7(495) 625-71-63; факс +7 (495) 650-27-31; Email: akimov@raasn.ru,pavel.akimov@gmail.com. 